\title{
ACCELERATED FORMATION OF CUSTOMARY INTERNATIONAL LAW
}

\author{
Michael P. Scharf
}

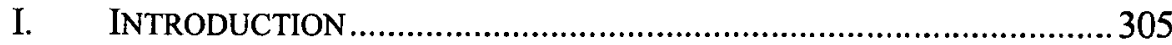

II. PRINCIPLES OF CUSTOMARY INTERNATIONAL LAW FORMATION .. 308

$A$. The Contemporary Importance of Customary International

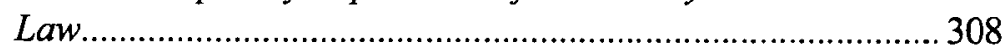

B. The Elements of Customary International Law....................... 310

1. The Objective Element...................................................312

a. Claim and Response Verses Articulation and Act...... 313

b. General Verses Constant and Uniform Practice........ 315

c. The Persistent Objector Rule...................................... 317

d. Treaties as Source of Custom..................................... 318

e. The Role of Judicial Decisions ................................... 320

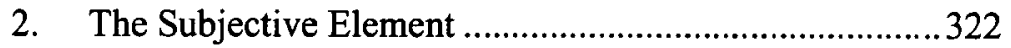

3. The Role of General Assembly Resolutions ....................324

4. The Sliding Scale Theory ...............................................328

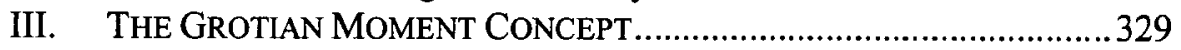

A. Nuremberg as Grotian Moment ............................................. 330

B. Other Examples of Grotian Moments Since World War II ..... 335

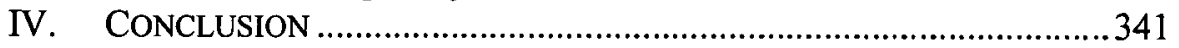

\section{INTRODUCTION}

By tradition, jurists, statesmen, and scholars have looked exclusively to two factors to divine whether an emergent rule has attained customary international law status: 1) widespread State practice and 2) manifestations of a conviction that the practice is required by international law. ${ }^{1}$ As a

* Interim Dean and John Deaver Drinko-Baker \& Hostetler Professor of Law, Case Western Reserve University School of Law. This article was based on a speech about my latest book, Customary International LaW In Times of Fundamental Change: Recognizing Grotian MOMENTS (Cambridge University Press, 2013), delivered at International Law Weekend 2013, sponsored by the American Branch of the International Law Association, on October 26, 2013.

1. On the international plane, customary international law is just as binding on a state as treaty law. A growing number of states' constitutions automatically incorporate customary law as part of the law of the land and even accord it a ranking higher than domestic statutes. Bruno Simma, International Human Rights and General International Law: A Comparative Analysis, in COLLECTED COURSES OF THE ACADEMY OF EUROPEAN LAW 153, 213 (1995). In the United States, customary international law is deemed incorporated into the federal common law of the United States, but some courts consider it controlling only where there is no contradictory treaty, statute, or executive act. See Garcia-Mir v. Meese, 788 F.2d 1446 (11th Cir. 1986) (holding that Attorney General's decision to 
companion to my book, Customary International Law in Times of Fundamental Change: Recognizing Grotian Moments, this article examines the largely overlooked role of a third factor-a context of fundamental change-that can serve as an accelerating agent, enabling customary international law to form much more rapidly and with less State practice than is normally thought to be possible. In these circumstances, General Assembly Resolutions and judgments of international tribunals often play a heightened role in "crystallizing" the newly emergent rule.

Historically, crystallization of new rules of customary international law was viewed as a protracted process that took decades, if not centuries, to complete. French jurisprudence generally required the passage of at least forty years for the emergence of an international custom, while German doctrine generally required thirty years. ${ }^{2}$ The International Law Commission (ILC), at the beginning of its work, demanded State practice "over a considerable period of time" for a customary norm to emerge. ${ }^{3}$ Indeed, the term crystallization is often employed by the International Court of Justice (ICJ) and scholars to equate formation of customary rules with the slow growth of crystalline minerals. But, as the ICJ noted in North Sea Continental Shelf, ${ }^{4}$ sometimes customary international law has formed much more rapidly, thus challenging this geologic metaphor.

detain Mariel Cuban refugees indefinitely without a hearing trumped any contrary rules of customary international law).

2. Vincy Fon \& Franscesco Parisi, The Formation of Customary Law 5 (George Mason Univ. Law, Working Paper No. 02-24, 2000), available at www.law.gmu.edu/assets/files/publications/working_papers/02-24.pdf (last visited Feb. 22, 2014); see G.I. Tunkin, Remarks on the Judicial Nature of Customary Norms in International Law, 49 CALIF. L. REV. 419, 420 (1961).

3. Manley O. Hudson, Special Rapporteur on Article 24 of the Statute of the Int'l Law Comm'n, Ways and Means for Making the Evidence of Customary International Law More Readily Available, Y.B. Int'l L. Comm'n, U.N. Doc. A/CN.4/16 (Mar. 3, 1950).

4. North Sea Continental Shelf (Ger. v. Den., Ger. v. Neth.), Merits, 1969 I.C.J. 3, ff 71, 7374 (Feb. 20) [hereinafter North Sea Continental Shelf]. The Court stated:

Although the passage of only a short period of time is not necessarily . . . a bar to the formation of a new rule of customary international law ... an indispensable requirement would be that within the period in question, short though it might be, State practice, including that of States whose interests are specially affected, should have been both extensive and virtually uniform in the sense of the provision invoked; and should moreover have occurred in such a way as to show a general recognition that a rule of law or legal obligation is involved.

Id. $\{$ 74. While recognizing that some norms can quickly become customary international law, the ICJ held that the equidistance principle contained in Article 6 of the 1958 Convention on the Continental Shelf had not done so as of 1969 because so few States recognized and applied the principle. At the same time, the Court did find that that Articles 1 and 3 of the Convention (concerning the regime of the continental shelf) did have the status of established customary law. 
In 2012, I was invited to tour the headquarters of the Kyocera Corporation in Kyoto, Japan, which is headed by the patron of Case Western Reserve University's Inamori Ethics Prize. Among the products Kyocera manufactures are re-crystallized gem stones. When looking at these artificially created diamonds, emeralds, and rubies, it occurred to me that just as Kyocera is able to create precious gem stones in a short time under intense heat and pressure, so too can a context of fundamental change intensify and accelerate the formation of customary international law.

Drawing from the writings of Professor Bruce Ackerman, who used the phrase "constitutional moment" to describe the New Deal transformation in American constitutional law, ${ }^{5}$ some international law scholars have used the phrase "international constitutional moment" to describe rapid paradigm shifts ${ }^{6}$ and transformative moments in international law. Stanford Law Professor Jenny Martinez, for example, has written that the drafting of the United Nations (U.N.) Charter was a "constitutional moment" in the history of international law. Washington University Law Professor Leila Sadat has similarly described Nuremberg as a "constitutional moment for international law." 8 Dean Anne Marie Slaughter from Princeton's Woodrow Wilson School and University of Pennsylvania Law School Professor William Burke-White have used the term "constitutional moment" in making the case that the September 11th attacks on the United States evidence a change in the nature of the threats confronting the international community, thereby paving the way for rapid development of new rules of customary international law. ${ }^{9}$ While the phrase "international constitutional moment" might be quite useful with

5. See generally BRUCE ACKERMAN, ReCONSTRUCTING AMERICAN LAW 19 (1984); see also Bruce ACKerman, We the People: TRANSFormations 385, 409 (1991).

6. THOMAS KUHN, THE STRUCTURE OF SCIENTIFIC REVOLUTIONS 150 (2d ed. 1970) (coining the phrase "paradigm shift").

7. Jenny S. Martinez, Towards an International Judicial System, 56 STAN. L. REv. 429, 463 (2003).

8. Leila Nadya Sadat, Enemy Combatants After Hamdan v. Rumsfeld: Extraordinary Rendition, Torture, and Other Nightmares from the War on Terror, 75 GEO. WASH. L. REv. 1200, 1206-07 (2007).

9. Anne-Marie Slaughter \& William Burke-White, An International Constitutional Moment, 43 HARV. INT'L L. J. 1, 2 (2002); see also Ian Johnstone, The Plea of "Necessity" in International Legal Discourse: Humanitarian Intervention and Counter-Terrorism, 43 COLUM. J. TRANSNAT'L L. 337, 370 (2005) (arguing that 9/11 constituted a "constitutional moment" leading to recognition of a newly emergent right to use force in self-defense argued against non-state actors operating with the support of third States). 
respect to paradigm-shifting developments ${ }^{10}$ within a particular international organization with a constitutive instrument that acts like a constitution, a different term is needed when speaking of a development in customary international law.

I have advocated the phrase "Grotian Moment," first coined by Princeton Professor Richard Falk, ${ }^{11}$ to capture this concept. Dutch scholar and diplomat Hugo Grotius (1583-1645) is widely considered to have laid the intellectual architecture for the Peace of Westphalia, which launched the basic rules of modern international law. ${ }^{12}$ While the results of Westphalia may have been simplified by the lens of history, and Grotius' role may have been exaggerated, ${ }^{13}$ Westphalia has unquestionably emerged as a symbolic marker and Grotius as an emblematic figure of changing historical thought. "Grotian Moment" thus seems like an apt label for transformational events in international law.

This article first reviews the scholarly debate about the nature and formation of customary international law. Then, examining case studies of rapid formation of customary international law, the article explores the role played by a context of fundamental change as an accelerating agent.

\section{PRINCIPLES OF CUSTOMARY INTERNATIONAL LAW FORMATION}

\section{A. The Contemporary Importance of Customary International Law}

To paraphrase Mark Twain, reports of the death of customary international law are "greatly exaggerated."

10. As defined by Thomas Kuhn in his influential book, THE STRUCTURE OF SCIENTIFIC REVOLUTIONS, a paradigm shift is a change in the basic assumptions within the ruling theory of science. While Kuhn opined that the term should be confined to the context of pure science, it has since been widely used in numerous non-scientific contexts to describe a profound change in a fundamental model or perception of events. One such example is the Keynesian Revolution in macroeconomic theory. ThOMAS KuHN, The Structure OF SCIENTIFIC Revolutions 150 (2d ed., 1970).

11. MichaEl P. SCHARF, CUSTOMARY INTERNATIONAL LAW IN TIMES OF FundamENTAL CHANGE: RECOGNIZING GROTIAN MOMENTS 17 (2013); see also INTERNATIONAL LAW AND WORLD ORDER 1265-86 (Bums H. Weston et al. eds., Thomson/West 4th ed. 2006). For the early seeds of this concept of a changing paradigm in Falk's work, see The Interplay of Westphalia and Charter Conceptions of International Legal Order, in THE FUTURE OF THE INT'L LEGAL ORDER 32 (R. Falk \& C. Black eds., 1969).

12. Hedley Bull et al., Hugo Grotius and InTERnational Relations 1, 9 (1992).

13. EdWARD KeENE, Beyond the ANarchical Society: Grotius, Colonialism, and ORDER IN WORLD POLITICS 45-52 (Cambridge University Press, 2002).

14. MARK TWAIN, BARTLETT'S FAMILIAR QuOTATIONS 625 (15th ed. 1980); David Bederman, Acquiescence, Objection and the Death of Customary International Law, 21 DUKE INT'L L. J. 31, 43 (2010). 
codification in treaties during the last century, the unwritten norms, rules, and principles of customary law continue to play a crucial role in international relations. ${ }^{15}$ There are three primary reasons for customary international law's continuing vitality.

First, in some ways, customary international law possesses more jurisprudential power than does treaty law. Unlike treaties, which bind only the parties thereto, once a norm is established as customary international law, it is binding on all States, even those new to a type of activity, so long as they did not persistently object during its formation. ${ }^{16}$ Since some international law rules co-exist in treaties and custom, customary international law expands the reach of the rules to those States that have not yet ratified the treaty. In addition, the customary international law status of the rules can apply to actions of the treaty parties that pre-dated the entry into force of the treaty. Moreover, States that were not even in existence at the time the norm evolved, such as colonies or former parts of a larger State, and therefore never had an opportunity to express their positions as a particular rule emerged, are nonetheless generally deemed to be bound by the entire corpus of customary international law existing upon the date they become sovereign States. ${ }^{17}$ Finally, unlike some treaties, which by their terms permit withdrawal, customary international law does not recognize a unilateral right to withdraw from it. ${ }^{18}$

Second, while one might tend to think of customary international law as growing only slowly, in contrast to the more rapid formation of treaties, the actual practice of the world community in modern times suggests that the reverse is more often the case. For example, negotiations for the Law of the Sea Convention began in 1973, the Convention was concluded in 1982, and did not enter into force until it received its sixtieth ratification in

15. Their definitions vary, but in ordinary usage the terms norms, principles and rules of customary international law are often used interchangeably, as they are here.

16. INT'L LAW ASS'N, LONDON CONFERENCE: COMMITTEE ON FORMATION OF CUSTOMARY (GENERAL) INTERNATIONAL LAW 25 (2000), available at http://www.ila-hq.org/en/ committees/index.cfm/cid/30 (last visited May 9, 2014) [hereinafter INT'L LAW Ass'N].

17. David Koplow, International Legal Standards and the Weaponization of Outer Space, in SPACE: THE NEXT GENERATION-CONFERENCE REPORT, UNITED NATIONS INST. FOR DiSARMAMENT RESEARCH 161 (2008).

18. Professors Bradley and Gulati criticize customary international law for failing to recognize a right to subsequently withdrawal from a customary rule in parallel with the right to withdraw from a treaty. See generally Curtis A. Bradley \& Mitu Gulati, Customary International Law and Withdrawal Rights in an Age of Treaties, 21 DuKE J. COMP. \& INT'L L. 1 (2010). Note, however, that not all treaties permit withdrawal. Moreover, there are situations, such as in a fundamental change of circumstances, where a State can be excused for failing to comply with a customary rule. See HERSCH LAUTERPACHT, THE FUNCTION OF LAW IN THE INTERNATIONAL COMMUNITY 66 (1933). 
1994 a period of twenty-one years. ${ }^{19}$ Similarly, negotiations for the Vienna Convention on the Law of Treaties began in 1949, the Convention was concluded in 1969, and did not enter into force until it received its thirty-fifth ratification in 1980 - some thirty-one years. ${ }^{20}$ And the ILC began its work on the Statute for an International Criminal Court in 1949, several preparatory committees then worked on it, and it was finally concluded in Rome in 1998 and entered into force upon receipt of its sixtieth ratification in 2002-a span of fifty-three years from start to finish. ${ }^{21}$ As we shall see below, customary international law often forms at a much faster pace, especially with respect to areas of technological or other fundamental change. ${ }^{22}$

Finally, one might assume that treaty law offers the benefit of greater clarity and precision in the articulation of the legal obligations, but this is not always the case. Rather, the provisions of treaties, especially multinational conventions, are also often subject to what H.L.A. Hart called a "penumbra of uncertainty" 23 resulting from the need to bridge language, cultural, legal, and political divides between diverse parties. In some areas, customary rules may provide greater precision since they evolve in response to concrete situations and cases, and are often articulated in the written decisions of international courts.

\section{B. The Elements of Customary International Law}

Hugo Grotius discerned the law of nations (jus gentium) from custom (usus), the views of the learned, and the will (voluntas) of States. ${ }^{24}$ In the centuries after Grotius, customary international law was deemed to constitute rules that develop through a "slow process of growth, whereby

19. U.N. Office of Legal Affairs, Div. for Ocean Affairs and the Law of the Sea, The United Nations Convention on the Law of the Sea (A Historical Perspective), UNITED NATIONS (1998), available at $\mathrm{http}: / / \mathrm{www} . \mathrm{un}$.org/depts/los/convention_agreements/convention_historical_perspective.htm (last visited Feb. 8, 2014).

20. Karl Zemanek, Vienna Convention on the Law of Treaties, UNITED NATIONS (May 23, 1969), available at http://legal.un.org/avl/pdf/ha/vclt/vclt-e.pdf (last visited May 9, 2014).

21. U.N. G.A., Rome Statute of the I.C.C., 17 July 1998, A/CONF.183/9 (2002).

22. In contrast to earlier times, in the modern era of instantaneous electronic communications, and a proliferation of diplomatic conferences, organizations and other forums for multinational diplomatic exchanges, State practice is being generated at an increasing pace, while information about state practice is becoming more and more widely disseminated over the internet. This means that the requisite quantity of claims and responses can be reached much more quickly than in the past leading to a general acceleration of the formation of customary rules. Tullio Treves, Customary International Law, in MAX PlanCK ENCYClOPEDIA OF PUB. INT'L LAW \ 25 (2006).

23. H.L.A. HART, THE CONCEPT OF Law 121-32, 144-50 (1961).

24. Hugo Grotius, Belli aC PaCIS ch. I, xiv (Kessinger Publ'g, 2004). 
courses of conduct once thought optional become first habitual or usual, and then obligatory, and the converse process of decay, when deviations, once severely dealt with, are first tolerated and then pass unnoticed."25

Article 38 of the Statute of the ICJ contains the modern definition of customary international law: "The Court, whose function is to decide in accordance with international law such disputes as are submitted to it, shall apply ... (b) international custom, as evidence of a general practice accepted as law." ${ }^{26}$ The text of Article 38 reflects the view that customary international law is composed of two elements: 1) general State practice, termed the "objective element;" and 2) some sort of attitude towards practice (be it acknowledgment as law or consent), termed the "subjective element." ${ }^{, 27}$ The judgments of the Permanent Court of International Justice (PCIJ) (the forerunner of the ICJ) and the ICJ have been consistent in stating that a customary rule requires the presence of both of these elements. Thus, in the 1929 S.S. Lotus, the PCIJ stated that international law is based on the will of States expressed in conventions or in "usages generally accepted as expressing principles of law." ${ }^{\text {28 }}$ Similarly, in the 1969 North Sea Continental Shelf, the ICJ stated that the actions by States "not only must amount to a settled practice, but they must also be such, or be carried out in such a way, as to be evidence of a belief that this practice is rendered obligatory by the existence of the rule of law requiring it."29

Where those two elements are manifest, a rule of customary international law will be deemed to bind all States, with the exception of persistent objectors, without it being necessary to show that the particular State allegedly bound by the rule has participated in its formation or has otherwise accepted it. ${ }^{30}$ This article focuses on general custom, that is, rules that apply world-wide. There is also such a thing as regional or local customary law, which can apply in a particular geographic area, e.g., to the States surrounding a bay, or in a particular sector-all the States that possess a particular technology, but that is not the subject of this inquiry.

25. HART, supra note 23, at 90.

26. 1945 I.C.J. Stat. 1055, T.S. No. 993. All member States of the United Nations are automatically parties to the Statute of the International Court of Justice.

27. Maurice H. MENDElson, The Formation of Customary International Law 195 (1998).

28. S.S. Lotus (Fr. v. Turk.), Merits, 1927 P.C.I.J. (ser. A) No. 10, at 18 (Sept. 7).

29. North Sea Continental Shelf, 1969 I.C.J. \ 77.

30. MENDELSON, supra note 27, at 218. 


\section{The Objective Element}

Traditionally, jurists and scholars have put more emphasis on State conduct than on the subjective element. That is because a State's conduct was traditionally easier to ascertain than the belief of a State. With the introduction of the U.N. and other bodies where multilateral diplomacy is conducted in the open, however, the situation has in fact reversed. ${ }^{31}$ State practice can be reflected in the acts of the judiciary, legislature, or executive branch of government. It comes in many forms, including: Diplomatic correspondence; declarations of government policy; the advice of government legal advisers; press statements, military manuals, votes and explanation of votes in international organizations; the comments of governments on draft texts produced by the ILC; national legislation, domestic court decisions; and pleadings before international tribunals. ${ }^{32}$

While one might be tempted to conclude that acts count more than words because "talk is cheap," virtually all of the authorities treat the two as equal. ${ }^{33}$ In fact, ICJ Judge Richard Baxter once noted, "the firm statement by the State of what it considers to be the rule is far better evidence of its position than what can be pieced together from the actions of that country at different times and in a variety of contexts. ${ }^{34}$ The case law of international tribunals is replete with examples of verbal acts being treated as examples of practice. ${ }^{35}$ In particular, diplomatic protest (or its absence) is universally viewed as important in determining whether a customary rule has been created or superseded. Thus, in assessing the relevant behavior of States, "we look to words as well as deeds, and to silences as well as inactions.",36 Verbal acts can count as either the objective or subjective element, and the International Law Association (ILA) has observed that it is possible for the same conduct to manifest both. ${ }^{37}$ As discussed below, State votes on U.N.

31. Id. at 197.

32. IAN BRownlie, PRINCiPles of PUblic INTERnational LaW 5 (4th ed., 1990).

33. INT'L LAW ASS'N, supra note 16, at 13-14.

34. Richard Baxter, Multilateral Treaties as Evidence of Customary International Law, 41 BRIT. YEAR BOOK OF INT'L L. 275, 300 (1965-1966).

35. See S.S. Lotus, 1927 P.C.I.J. at 23, 26-30; Nottebohm Case (Lich. v. Guat.), 1955 I.C.J. 4, ๆף 21-23 (Apr. 6); Fisheries Jurisdiction (U.K. v. Ice.), Merits, 1974 I.C.J 3, at 24-26, ๆf 55-58 (July 25); Military and Paramilitary Activities in and Against Nicaragua (Nicar. v. U.S.), Merits, 1986 I.C.J. 14, at 97-109, 19 183-207 (June 27) [hereinafter Nicaragua Case]; Legality of the Threat or Use of Nuclear Weapons, Advisory Opinion, 1996 I.C.J. 226, at 259-61, ๆๆ 86, 88 (July 8) [hereinafter Nuclear Weapons Advisory Opinion]; Gabcikovo-Nagymaros Project (Hung./Slovk.), 1997 I.C.J. 7, Iף 49-54, 83, 85 (Sept. 25).

36. Koplow, supra note 17 , at 160.

37. INT'L LAW ASS'N, supra note 16, at 7. 
General Assembly Resolutions can thus be both a form of State practice and a manifestation of the State's subjective attitude about the existence of the rule in question. ${ }^{38}$

State practice also includes inaction or silence, especially (but not necessarily) where a protest would be expected. Thus, in the case of the S.S. Lotus, the PCIJ relied on the absence of protest against legislation based on the "objective territoriality" doctrine of jurisdiction in finding that such an exercise of jurisdiction was permissible under customary international law. ${ }^{39}$ Similarly, in the Nottebohm Case (second phase), the ICJ based its decision on the fact that some States "refrain from exercising protection in favor of a naturalized person when the latter has in fact, by his prolonged absence, severed his links with what is no longer for him anything but his nominal country ....,40

\section{a. Claim and Response Verses Articulation and Act}

Professor Myers McDougle of Yale Law School famously described the customary international law formation process as one of continuous claim and response. ${ }^{41}$ To illustrate this process, consider the question of whether international law permits a State to use force to arrest a terrorist leader in another State without the latter's consent-a question that recently arose when the United States kidnapped an al-Qaeda leader from Libya in October 2013. ${ }^{42}$ The claim may be express, such as demanding that its special forces be allowed to enter the territorial State to arrest the terrorist, or implicit, such as sending its special forces into the territorial State without its permission to apprehend the terrorist. The response to the claim may in turn be favorable, such as consenting to the operation or refraining from protesting the extraterritorial apprehension. In such case, the claim and response will begin the process of generating a new rule of customary international law. Some States may imitate the practice and others may passively acquiesce in it.

"Custom pioneers" (the first State to initiate a new practice) have no guarantee that their action will actually lead to the formation of a binding custom. Indeed, the response may be a repudiation of the claim, as in the

38. MENDELSON, supra note 27, at 201.

39. S.S. Lotus, 1927 P.C.I.J. at 23.

40. Nottebohm Case, 1955 I.C.J. at 22.

41. See generally M.S. McDougal \& N.A. Schlei, The Hydrogen Bomb Tests in Perspective: Lawful Measures for Security, 64 YALE L. J. 648 (1955).

42. Emesto Londoño, Capture of Bombing Suspect in Libya Represents Rare 'Rendition' by U.S. Military, WASHINGTON POST (Oct. 6, 2013), available at http://articles.washingtonpost.com/201310-06/world/42771116_1_kerry-terrorism-suspects-libyan-govemment (last visited Feb. 22, 2014). 
case of Libya's protest of the un-consented apprehension of the al-Qaeda operative. ${ }^{43}$ In such case, the repudiation could constitute a reaffirmation of existing law, which is strengthened by the protest. Or, the claim and repudiation could constitute a stalemate, which could decelerate the formation of new customary international law. The reaction of Third States is also relevant. Out of this process of claim and response, and third party acquiescence or repudiation, rules emerge or are superseded. Just "as pearls are produced by the irritant of a piece of grit entering an oyster's shell, so the interactions and mutual accommodations of States produce the pearl-so to speak —of customary law." ${ }^{, 44}$

Professor D'Amato, of Northwestern University, has proposed an alternative formulation to explain the formation of customary rules, focusing on what he calls "articulation" and "act." the articulation can either accompany the initial act (what McDougal called the "claim"), or it can be embodied in a treaty, draft instruments of the ILC, or resolutions of the U.N. General Assembly, ${ }^{46}$ Acts that follow and are consistent with the articulation will crystallize the policy into a principle that takes on life as a rule of customary international law. ${ }^{47}$ In other words, once there is a consensus articulation that States ought to conform to a given rule of conduct, a legal custom can emerge when some level of spontaneous compliance with the rule is manifest.

Advocates of D'Amato's approach have called it "modern custom." In contrast with the inductive claim and response process McDougal describes, so-called modern custom is "a deductive process that begins with general statements of rules rather than particular instances of practice.,49 Where McDougal's claim and response concept is backward looking, D'Amato's conception is more like treaty law, proscribing rules for the future. Yet, of the two approaches, many scholars believe McDougal's claim and response concept better reflects the "authentic world of politics, rather than some ideal world which may owe more to rhetoric than to reality." 50

43. Id.

44. MENDELSON, supra note 27, at 190.

45. ANTHONY A. D'AMATO, CONCEPT OF CUSTOM IN INTERNATIONAL LAW 88 (1971).

46. Id.

47. $J d$.

48. Anthea E. Roberts, Traditional and Modern Approaches to Customary International Law: A Reconciliation, 95 AM. J. INT’L L. 757, 757 (2001).

49. Id. at 758.

50. MENDELSON, supra note 27, at 190-91. 


\section{b. General Verses Constant and Uniform Practice}

Although the ICJ has spoken of "constant and uniform usage" as the yardstick for ascertaining a customary rule,${ }^{51}$ the Court has made clear that perfect consistency is not required. Based on its comprehensive examination of the Court's case law, the ILA has observed that "general practice suffices" to generate customary rules binding on all States. ${ }^{52}$ In Fisheries Jurisdiction, the Court stressed that "too much importance need not be attached to the few uncertainties or contradictions" in State practice. $^{53}$ Similarly, the Court determined that although various proclamations of an exclusive economic zone were not identical, they were sufficiently similar for the Court to hold in the Continental Shelf cases between Tunisia and Libya, and between Libya and Malta, that the Exclusive Economic Zone (EEZ) had become part of customary international law. ${ }^{54}$ And, in concluding that the rule against use of force in the territory of another State was part of customary international law in the 1986 Nicaragua Case, the Court said:

[It] does not consider that, for a rule to be established as customary, the corresponding practice must be in absolutely rigorous conformity with the rule. In order to deduce the existence of customary rules, the Court deems it sufficient that the conduct of States should, in general, be consistent with such rules....5

The ICJ has also spoken of the requirement of "extensive" practice, and at the same time has indicated that the most important practice is that of "States whose interests are specially affected." This means discerning the existence of a customary rule is not merely a numbers game; there is an important qualitative aspect to the inquiry. In other words, it may be enough that the practice be representative, so long as it includes States whose interests are specially affected. Thus, in Continental Shelf (Libya/Malta), the Court determined that, after several significant maritime States had claimed EEZs, the EEZ had ripened into a rule of customary international law despite the fact that a majority of eligible coastal States

51. Asylum (Colom./Peru), 1950 I.C.J. 266, at 276 (Nov. 20).

52. INT'L LAW Ass'N, supra note 16, at 24.

53. Fisheries Jurisdiction (U.K. v. Nor.), 1951 I.C.J. 116, at 138 (Dec. 18).

54. Continental Shelf (Tunis./Libya), 1982 I.C.J. 18, at 74, $¥ 100$ (Feb. 24); Continental Shelf (Libya/Malta), 1985 I.C.J. 13, at 33, f 34 (June 3).

55. Nicaragua Case, 1986 I.C.J. at 98, |f 186.

56. North Sea Continental Shelf, 1969 I.C.J. at 43, ๆ 74. 
had not yet claimed an EEZ. ${ }^{57}$ Similarly, in the Frontier Dispute (Burkina Faso/Mali), the Court held that uti possidetis was a rule of general customary international law, even though at the time the principle was supported only in the practice of Spanish American and African States which did not constitute a majority of the international community. ${ }^{58}$

To understand the significance of specially affected States, Professor Charles De Visscher of Ghent University likened the formation of custom to the gradual wearing of a path through a field: "Among the users are always some who mark the soil more deeply with their footprints than others, either because of their weight . . . or because their interests bring them more frequently this way." 59 This metaphor helps explain why the most important States in the particular area of activity (which may or may not be the most powerful States generally) should be accorded extraordinary weight. A State especially active in an area will likely devote more resources to thinking about and developing the applicable law. Thus, the United States and United Kingdom were pioneers of the regime of the continental shelf because their nationals were the first to be actively engaged in offshore oil exploitation in areas beyond the territorial sea. ${ }^{60}$ Similarly, the United States and Soviet Union were pioneers of early space law since they were the first States to be capable of such flight. ${ }^{61}$

Just as the practice of specially affected States can have a disproportionate influence on the formation of new rules, so too can their opposition prevent a rule from coming into being. A prominent example of this is the successful opposition of the United States and other capitalexporting countries to the replacement of the "prompt, adequate and effective" standard of compensation in cases of lawful expropriation, with a lower standard of "just compensation" advocated by a majority of States. ${ }^{62}$

The ILA has concluded that "provided that participation is sufficiently representative, it is not normally necessary for even a majority of States to have engaged in the practice, provided that there is no significant dissent." According to Professor Michael Barton Akehurst of Keele University,

57. See generally Continental Shelf, 1985 I.C.J. at 13..

58. Frontier Dispute (Burk. Faso/Mali), 1986 I.C.J. 554, at 564-65, fil 19-20 (Jan. 10). The uti possidetis principle requires that a newly independent State respect preexisting external borders.

59. C. DE VISSCHER, THEORY AND REALITY IN PUBLIC INTERNATIONAL LAW 155 (1968).

60. See generally MICHAEL P. SCHARF, CUSTOMARY INTERNATIONAL LAW IN TIMES OF Fundamental ChANGE: RECOGNIZING GROTIAN MOMENTS 107-22 (2013).

61. See generally id. at 123-38.

62. M. H. Mendelson, What Price Expropriation? Compensation for Expropriation: The Case Law, 79 AM. J. INT'L L. 414, 414 (1985).

63. INT'L LAW ASs'N, supra note 16, at 25. 
where there is no evidence presented against a rule of customary international law, a small amount of practice is sufficient to prove the existence of such rule, resting the burden of disproving its existence on the objecting party. ${ }^{64}$ Consistent with this, scholars who have carefully dissected the judgments of the ICJ have concluded that "most customs are found to exist on the basis of practice by fewer than a dozen States.",65

A final consideration is whether the situation is one of initial formation of a customary rule or the alteration of existing customary law. Scholars have argued that existing customs should not be lightly discarded. As Professor Bederman explained, "there should be a higher threshold of uniformity, consistency and volume of State practice in order to terminate an old, well-settled customary rule, as opposed to creating a new one in a hitherto unregulated realm of international relations. ${ }^{, 66}$

\section{c. The Persistent Objector Rule}

The international community is not yet ready to accept a system in which the majority, or a minority consisting of especially affected States, can develop new rules of customary international law and also bind the remaining States to the new rules over their objection. Thus, a state that does not wish to acquiesce in the development of a new rule of customary international law can rely on the so-called "persistent objector rule." Reflecting the voluntary nature of customary international law, a State which manifests its opposition to a practice before it has developed into a rule of customary international law can, by virtue of that objection, opt out from the operation of the new rule.

While the persistent objector rule is of relatively modern recognition, it has been treated by jurists and scholars as practically axiomatic. ${ }^{67}$ The ICJ recognized the persistent objector rule in the Asylum Case, where the Court stated, "[b]ut even if it could be supposed that such a custom existed between certain Latin-American States only, it could not be invoked against Peru which, far from having by its attitude adhered to it, has, on the contrary, repudiated it ...."68 The Court also applied the rule in Fisheries

64. M. Akehurst, Custom as a Source of International Law, 47 BRIT. YEAR BOOK OF INT'L LAW 1, 12 (1974-1975).

65. Roberts, supra note 48, at 767 (citing the works of Chamey, Chodosh, Schacter, and Weisburd).

66. Bederman, supra note 14 , at 38 .

67. MENDELSON, supra note 27, at 227 (citing the works of R. Y. Jennings, C. Rousseau, J.H.W. Verzijl, I. Brownlie, G.I. Tunkin, H. Thirlway, M. Villiger, K. Wolfke, G. Danilenko, and C. van Bynkershoek).

68. Asylum, 1950 I.C.J. at 276. 
Jurisdiction, in rejecting the United Kingdom's argument that customary international law limited closing lines in bays to a length of ten miles. ${ }^{69}$ The Court stated, "[i]n any event the ten-mile rule would appear to be inapplicable to Norway, inasmuch as she has always opposed any attempt to apply it to the Norwegian coast.,"70

The persistent objector rule has certain limits. First, if a State does not make an objection at the time the general rule is emerging, it can be considered bound despite subsequent manifestations of opposition. ${ }^{71}$ Second, customary international law rules are binding on new States and existing States that are newcomers to a particular type of activity. There is no "subsequent objector" rule available to such States." Third, the rule does not apply to peremptory norms (jus cogens). ${ }^{73}$ Thus, although South Africa persistently maintained that it was entitled to practice apartheid, the international community accorded no weight to this objection. There have been few instances of invocation of the persistent objector rule, but it is nonetheless considered an important safety valve that permits the "convoy" of customary international law to move forward without having to wait for the slowest member. ${ }^{74}$

\section{d. Treaties as Source of Custom}

Treaties are binding on their parties, but they can also generate customary rules binding on all States in three ways: First, treaties can codify and elucidate customary international law. This may seem counterintuitive since traditionally, the purpose of treaties was to derogate from existing customary law, not to confirm it. In the years since its establishment by the U.N. General Assembly in 1945, however, the ILC has promulgated a number of international conventions meant to transform customary international law into treaty law. Yet, one should not assume that every provision of a codifying treaty constitutes customary law. A particular treaty might well contain some provisions meant to reflect existing customary law, and others, which constitute progressive development. Thus, in North Sea Continental Shelf, the ICJ found that Article 6 (the equal distance rule) of the Geneva Convention on the

\footnotetext{
69. Fisheries, 1951 I.C.J. at $116, \uparrow 131$.

70. Id.

71. INT'L LAW ASS'N, supra note 16, at 27.

72. Id.

73. Id. at 28.

74. MENDELSON, supra note 27, at 240.
} 
Continental Shelf did not represent customary law, but that Articles 1 and 3 (concerning the regime of the continental shelf) did. ${ }^{75}$

Sometimes a treaty will expressly declare that its provisions, or certain of them, are declaratory of existing customary law. For example, Article 1 of the Genocide Convention provides "[ $t]$ he Contracting Parties confirm that genocide, whether committed in time of peace or in time of war, is a crime under international law which they undertake to prevent and to punish." ${ }^{76}$ Such a provision is strong but not conclusive evidence, for in some cases States have strategically included such provisions to bolster their case vis-à-vis third parties. ${ }^{77}$ In other occasions the Treaty's negotiating record (travaux preparatoires) will indicate whether the Treaty was intended as a codification or not. Even in the absence of such a provision or reference in the negotiating record, Courts may find that a provision of a treaty constitutes a codification of customary law. Thus, in the Namibia Case, the ICJ held that "the rules laid down by the Vienna Convention on the Law of Treaties concerning termination of a treaty relationship on account of breach (adopted without a dissenting vote) may in many respects be considered as a codification of existing customary law on the subject" and went on to apply those rules as customary law to the South-West Africa Mandate which predated the Vienna Convention. ${ }^{78}$

Second, the consensus formed through the process of treaty negotiation can sometimes crystallize rules of customary international law as reflected in the treaty text before the treaty comes into force. In North Sea Continental Shelf, Denmark argued that "the process of the definition and consolidation of the emerging customary law took place through the work of the ILC, the reaction of governments to that work and the proceedings of the Geneva Conference [on the Law of the Sea]." ${ }^{, 79}$ While recognizing that treaty provisions could conceivably crystallize customary law, the ICJ held that this was not the case with respect to Article 6 of the Geneva Convention on the Continental Shelf. ${ }^{80}$ In contrast, in Continental Shelf (Tunisia/Libya), the ICJ concluded that the recently concluded, though not yet in force, 1982 Convention on the Law of the Sea

75. North Sea Continental Shelf, 1969 I.C.J. q1 24-33.

76. Convention Against Genocide, 78 U.N. Treaty Series, 278 (1948).

77. See W.E. Hall, A Treatise on International Law 9 (A. Pearce Higgins, 8th ed., 1924) (listing examples of such treaties).

78. Legal Consequences for States of Continued Presence of South Africa in Namibia, Advisory Opinion, 1971 I.C.J. 16, at 47, 994 (June 21).

79. North Sea Continental Shelf, 1969 I.C.J. at 52.

80. Id. at 38 , $1961-62$. 
"crystallizes" an "emergent rule of customary law." " The same principle has been applied to draft Articles produced by the U.N.'s ILC experts after years of study and debate, including comments by governments. Thus, the ICJ concluded in Gabcikova-Nagymaros that the requirements for invoking a state of necessity set out in the Draft Articles on State Responsibility adopted on first reading by the ILC "reflect customary international law." 82

Third, a rule enshrined in a treaty may commend itself to States generally, who then adopt it in practice even if they fail to become parties to the treaty. For example, a treaty known as the 1856 Declaration of Paris abolished privateering (government-sanctioned piracy against the vessels of enemy States) ${ }^{83}$ While very few States became parties to the instrument, it is widely recognized that the outlawry of privateering became a rule of general customary law through State practice inspired by the Declaration. ${ }^{84}$

\section{e. The Role of Judicial Decisions}

Judicial decisions count both as a form of State practice within the meaning of Article 38 of the Statute of the ICJ, and as a "subsidiary means for the determination of rules of law" within paragraph (d) of that Article. ${ }^{85}$ Scholars debate whether this applies not just to decisions of domestic courts, but to those of international tribunals as well.

On the one hand, Professor Maurice Mendelson, the Chair of the ILA's Customary International Law Committee, argues that decisions of international tribunals should not be deemed State practice because international judges are supposed to act independently of those appointing them. ${ }^{86}$ The Max Planck Encyclopedia of Public International Law, on the other hand, maintains that:

81. Continental Shelf, 1982 I.C.J. at 54, \24.

82. Gabcikovo-Nagymaros Project, 1997 I.C.J. ๆ 52.

83. SCHARF, supra note 11 , at 44.

84. MENDELSON, supra note 27, at 193.

85. In practice, the significance of decisions of intemational courts and tribunals is much greater than what emerges from Article $38(1)$ (d) of the ICJ Statute, which characterizes judicial decisions merely as "subsidiary means for the determination of rules of law." Despite the absence of formal stare decisis in this realm, international and domestic courts tend to rely on the precedents of international tribunals, and States and parties to proceedings expect them to do so. Michael P. Scharf \& Margaux Day, The International Court of Justice's Treatment of Circumstantial Evidence and Adverse Inferences, 13 CHI. J. OF INT'L L. 123, 128 (2012). Moreover, international courts and tribunals can assess the existence and contents of customary rules on the basis of an unparalleled amount of materials, represented to them through written and oral pleadings, including annexes of relevant materials, very often unearthed from archives for the purpose of the case. Treves, supra note 22, \55.

86. MENDELSON, supra note 27 , at 200 . While this may be true of some international tribunals, it is not necessarily the case with respect to the International Court of Justice. Where a case 
[A]s the authority of international courts and tribunals to settle a dispute between States derives from agreement of the States involved, judgments of such courts and tribunals may be seen, indirectly, as manifestations of the practice of the States that have agreed to confer on them such authority and the mandate to apply international-including customary-law. ${ }^{87}$

Moreover, as Professor Karol Wolfke of Wroclaw University in Poland points out, "the fact that States accept the judgments and opinions of judicial organs means that those decisions and opinions can themselves be regarded as a form of State practice." ${ }^{18}$ Consistent with this, in 1950, the ILC included decisions of international courts in its list of primary sources of customary international law. ${ }^{89}$

In Fisheries Jurisdiction, the ICJ stated that its role is to ascertain the existence of rules of customary international law, not to create them. ${ }^{90}$ Yet, the Court subsequently acknowledged its broader role in contributing to the formation of customary international law in the Nuclear Weapons Advisory Opinion, where the Court observed: "In stating and applying the law, the Court necessarily has to specify its scope and sometimes note its general trend." ${ }^{.91}$ Thus, Professor Anthea Roberts of London School of Economics concludes that "judicial decisions can also have a formative effect on custom by crystallizing emerging rules and thus influencing state behavior." ${ }^{92}$

involves the judge's State of nationality, Article 31 of the ICJ Statute provides that the opposing party may appoint an ad hoc judge to the bench so that both parties enjoy the same advantage. This implicitly recognizes that international judges are prone to be particularly sympathetic to the interests of the judge's State of nationality. Nor would Mendelson's observation apply to the Nuremberg Tribunal, which was made up of judges representing the four great powers that emerged victorious at the end of World War II. One of the criticisms of the Nuremberg Tribunal was that it represented victors' justice and that the judges were not sufficiently independent from their appointing States. See A. BRACKMAN, THE OtHer NuREMBERG 63, 69 (1987); R. CONOT, JustiCE AT NUREMEBERg 62 (1983); A. TUSA \& J. TUSA, THE NUREMBERG TRIAL 12 (1983).

87. Treves, supra note $22, \mathbb{\Upsilon} 53$.

88. INT'L LAW ASS'N, supra note 16, at 19.

89. The International Law Commission listed the following sources as forms of evidence of customary international law: Treaties, decisions of national and international courts, national legislation, opinions of national legal advisors, diplomatic correspondence, and practice of international organizations. 2 Y.B. INT'L L. COMM'N 367, U.N. Doc. A/CN.4/Ser.A/1950/Add.1 (1957).

90. Fisheries Jurisdiction, 1974 I.C.J. I 53 (The Court stressed that "the Court, as a court of law, cannot render judgment sub specie legis ferendae, or anticipate the law before the legislator has laid it down.").

91. Nuclear Weapons Advisory Opinion, 1996 I.C.J. \18.

92. Roberts, supra note 48 , at 775 . 


\section{The Subjective Element}

The purpose of the subjective element, known as opinio juris, is to differentiate State actions that give rise to legal norms from actions that do not. ${ }^{93}$ The subjective element has been described as "the philosopher's stone which transmutes the inert mass of accumulated usage into the gold of binding legal rules." ${ }^{.94}$ This element is necessary because State practice is often capable of being interpreted in various ways. Examining subjective intent is particularly important where actions (or omissions) are in and of themselves ambiguous. For example, Professor D'Amato has said that every breach of a customary law contains the seed for a new legality. ${ }^{95}$ But that is only the case if the breaching State justifies its action on the basis of a new rule of customary law. As the ICJ observed in the Nicaragua Case, if instead the State resorts to factual or legal exceptions to justify the breach, this has the effect of confirming the general rule rather than undermining it or creating an exception to it. ${ }^{96}$

Moreover the subjective element can reveal actions that constitute mere comity and distinguish those taken out of mere convenience from those that count as precedents. Take, for example, the S.S. Lotus. There, France argued that the dearth of prosecutions for collisions on the high seas other than by the flag State on board which the wrongful act took place was evidence that international law did not recognize "effects jurisdiction" in such cases. ${ }^{97}$ The PCIJ disagreed on the ground that there was no evidence of a "conscious[ness] of having a duty to abstain" from prosecuting officers of ships of foreign registry for injuries to ships of domestic registry. ${ }^{98}$ The reasons for lack of prosecution could just as easily have been based on lack of interest or lack of domestic statutory authority as on a belief that such prosecutions violated customary international law.

There are two vigorously contested schools of thought concerning the nature and role played by the subjective element. The "voluntarist" thesis maintains that, since States are sovereign, they cannot be bound by legal obligations (whether through treaty or customary law) without their consent. Consistent with this, voluntarists view the subjective element of customary international law as a manifestation of consent. The competing "belief" thesis maintains that custom's binding force is based in the States"

\footnotetext{
93. INT'L LAW ASS'N, supra note 16, at 10.

94. H. THIRLWAY, INTERNATIONAL CUSTOMARY LAW AND CODIFICATION 47 (1972).

95. D'AMATO, supra note 45, at 97-98.

96. Nicaragua Case, 1986 I.C.J. at 98, ๆ 186.

97. S.S. Lotus, 1927 P.C.I.J. at 28.

98. Id.
} 
belief in the legal necessity or permissibility of the practice in question. The controversy between supporters of the two approaches goes back more than 200 years, and has continued to this day. ${ }^{99}$

The voluntarist thesis has been criticized for adopting the legal fiction that silence is considered a form of acquiescence or tacit consent-a fiction that is particularly hard to buy in cases where the particular State was not directly affected by the conduct in question when the customary rule was being formed. ${ }^{100}$ The belief thesis, in turn, has been criticized for failing to explain how opinio juris can exist in the initial phase of State practice with respect to a new rule. If it is the first State to assert a new rule, how can the State seriously entertain the opinion that it is acting in accordance with the law? Some commentators have tried to answer this criticism by suggesting that the State could be acting in error, but "the truth is that the State which introduces a new practice has in these cases no belief that its conduct is permitted or required by existing law, and neither have the first States to respond positively or negatively to its conduct." ${ }^{101}$ As Judge Lachs observed in his opinion in North Sea Continental Shelf, to require a conviction that the conduct is already a matter of legal obligation is to deny the possibility of developing new rules of customary law. ${ }^{102}$ It is more likely in such a case that the pioneers of the customary rule know that they are breaking new ground but purposely couch their innovation in the language of existing law to make it more palatable to other States. ${ }^{103}$

Some scholars believe that the dichotomy between the two approaches is a false one; that consent plays a role in some circumstances, and belief does in others. ${ }^{104}$ Professor Mendelson, for example, maintains that the voluntarist thesis is the better approach to the question of the formation of customary rules, and the approach, which emphasizes belief, better explains why mature customary rules are observed. ${ }^{105}$ Consistent with the words in Article 38 of the Statute of the ICJ, "a general practice accepted as law," Mendelson suggests that in the early formation stage "acceptance" means consent to an emerging rule, and in the later stage "acceptance" means acknowledgment that the rule has gained the force of law. ${ }^{106}$ Moreover, he

99. MENDELSON, supra note 27, at 246 n.244 (citing diametrically opposed articles).

100. INT'L LAW Ass'N, supra note 16, at 39.

101. MENDELSON, supra note 27, at 280.

102. North Sea Continental Shelf, 1969 I.C.J. at 218, 231.

103. This was the case of the United States formulation of the Truman Declaration, which created the legal concept of the continental shelf in 1945. See SCHARF, supra note 11, at 5.

104. MENDELSON, supra note 27, at 248.

105. Id. at 283.

106. Id. 
stresses that such an acknowledgment need not come from States alone, but could emanate from a tribunal ${ }^{107}$ or from a resolution of the U.N. General Assembly. ${ }^{108}$

\section{The Role of General Assembly Resolutions}

One of the most striking developments related to the formation of customary international law in modern times has been the year-round functioning of international organizations and their various organs. This gives States many more occasions than they used to have to express views as to customary international law. In recent years there has been a stream of resolutions from international organizations, especially the U.N. General Assembly, purporting to set forth, confirm, or reaffirm rules of customary international law. Consistent with the premise that words count as State practice, some jurists and scholars have argued that, when adopted unanimously or by large majorities, General Assembly resolutions can constitute both the objective and subjective elements necessary to establish customary international law, and thereby can create so-called "instant custom." 109

There are five main criticism of the so-called "instant custom" theory. The first is that the U.N. Charter employs the language of "recommend" in referring to the powers and functions of the General Assembly, as distinct from the powers granted to the Security Council to issue binding decisions. ${ }^{110}$ The negotiating record of the U.N. Charter confirms that the drafters intended for General Assembly resolutions to be merely nonbinding recommendations. In fact, at the San Francisco Conference in 1945, when the Philippines delegation proposed that the General Assembly

107. Id. at 396 (Mendelson points out that in "certain innovative decision" such as the 1951 Fisheries Jurisdiction case, the Reservations to the Genocide Convention cases, and the Nottebohm Case, "it would not be far from the truth to say that the ICJ made new law.").

108. MENDELSON, supra note 27, at 283.

109. KHURSHID IQBAL, ThE RIGHT to DEVELOPMENT IN INTERNATIONAL LAW: THE CASE OF PAKISTAN 120 (2010); in his dissenting opinion in the South West Africa Cases (Eth. v. S. Afr.), 1966 I.C.J. Rep. 248, 291-93, Judge Tanaka argued that when a court is trying to discern whether a certain customary norm of international law exists, General Assembly Resolutions can be used as evidence of general practice. Id. at 291. He suggested that the General Assembly can accelerate the formation of customary law by serving as a forum in which a state "has the opportunity, through the medium of the organization, to declare its position to all members of the organization and to know immediately their reaction on the same matter." Id.

110. See generally U.N. Charter arts. 10-11. 
be vested with legislative authority to enact rules of international law, the other delegations voted down the proposal by an overwhelming margin. ${ }^{111}$

The second problem is that General Assembly resolutions often do not clearly differentiate between what the law is (lex lata) and what the law should be (lex ferenda). Often resolutions reflect lex ferenda cloaked as lex lata. Citing the Manila Declaration on the Peaceful Settlement of International Disputes ${ }^{112}$ as an example, Professor Roberts observes that General Assembly resolutions "often reflect a deliberate ambiguity between actual and desired practice, designed to develop the law and to stretch the consensus on the text as far as possible." 113

The third problem is that States often vote for General Assembly resolutions to embellish their image or carry favor with other States, without the expectation that their votes will be deemed acceptance of a new rule of law. For example, the United States initially opposed the draft of General Assembly Resolution 1803, which mandated "appropriate compensation" following an expropriation because the United States felt that the correct standard should be "prompt, adequate, and effective" compensation. ${ }^{14}$ Yet, the United States ultimately voted in favor of the resolution in a spirit of compromise. ${ }^{15}$ ICJ Judge Stephen Schwebel has referred to this type of practice as "fake consensus."

The fourth problem is that even if statements and votes in the General Assembly can qualify as either State practice or manifestations of opinio juris, counting the same action as both presents a skewed picture. Related to this, the fifth problem with an approach that focuses exclusively on words contained in non-binding General Assembly Resolutions is "that it is

111. Gregory J. Kerwin, The Role of United Nations General Assembly Resolutions in Determining Principles of International Law in United States Courts, 1983 DUKE L. J. 876, 879 (1983).

112. G.A. Res. 37/10, U.N. Doc. A/RES/37/10 (Nov. 14, 1982).

113. Roberts, supra note 48 , at 763 .

114. G.A. Res.1803 (XVII), 17 U.N. GAOR Supp. (No.17) at 15, U.N. Doc. A/5217 (Dec. 14, 1962); Banco Nacional de Cuba v. Chase Manhattan Bank, 658 F.2d 875, 890 (2d Cir. 1981).

115. Banco Nacional de Cuba, 658 F.2d at 890 (Opining that General Assembly Resolutions "are of considerable interest" but they "do not have the force of law;" the Court held that expropriation requires "prompt, adequate, and effective compensation" rather than the standard of "appropriate compensation" reflected in General Assembly Resolution 1803.).

116. Stephen M. Schwebel, The Effect of Resolutions of the U.N. General Assembly on Customary International Law, 73 AM. SOC'Y. OF INT'L. L. PROC. 301, 308 (1979). Schwebel has observed that members of the U.N.:

Often vote casually ... States often don't meaningful support what a resolution says and they almost always do not mean that the resolution is law. This may be as true or truer in the case of unanimously adopted resolutions as in the case of majority-adopted resolutions. It may be truer still of resolutions adopted by consensus. Id. at 302 . 
grown like a flower in a hot-house and that it is anything but sure that such creatures will survive in the much rougher climate of actual state practice." 117 Elsewhere I have argued that outside of situations covered by treaties with a "prosecute or extradite" requirement, the so-called "duty to prosecute" crimes against humanity, recognized in non-binding General Assembly resolutions, is a chimera. ${ }^{118}$ A "rule" that is based only on General Assembly resolutions is unlikely to achieve substantial compliance in the real world, and therefore will end up undermining rather than strengthening the rule of law. As Professor Roberts puts it, "deducing modern custom purely from opinio juris can create utopian laws that cannot regulate reality." 119

On the other hand, General Assembly resolutions share with treaties the advantage of being written documents whose contents can be expressed with precision. While it is a radical position to argue that such resolutions constitute autonomous sources of international law, few scholars would dispute that General Assembly resolutions can codify and elucidate existing rules or inspire future development of customary international law in the same way that a multinational treaty can. More controversial is the question of whether the adoption of General Assembly Resolutions can play a role in crystallizing emerging rules of customary international law ${ }^{120}-a$ phenomenon colorfully described by Professor David Koplow of Georgetown as "helping to midwife the development of new norms of customary international law." In the words of the Institute of International Law, "where a rule of customary law is (merely) emerging or there is still some doubt as to its status, a unanimous resolution can consolidate the custom and remove doubts which might have existed."122

While some scholars have argued that "customary law without custom (practice) is a contradiction in terms," the ILA has pointed out that since statements are a form of State practice, how a State votes and how it

\section{Simma, supra note 1 , at 217 .}

118. Michael P. Scharf, Swapping Amnesty for Peace: Was there a Duty to Prosecute International Crimes in Haiti?, 31 TEX. INT'L. L.J. 1, 41 (1996) (citing examples of adverse state practice where amnesty is traded for peace, thus disproving the existence of a customary rule requiring prosecution in the absence of a treaty with a prosecute or extradite provision).

119. Roberts, supra note 48. Similarly, Niels Petersen of the Max Planck Institute has stated the reason for requiring practice as a constituent element of customary law is that "law should not consist of abstract, utopian norms, but rather be affiliated with social reality." Niels Peterson, Customary Law Without Custom? Rules, Principles, and the Role of State Practice in International Norm Creation, 23 AM. U. INT'L L. REV. 275, 301 (2008).

120. Jonathan I. Chamey, Universal International Law, 87 AM. J. INT'L L. 529, 547 (1993).

121. Koplow, supra note 17, at 162.

122. INT'L LAW ASS'N, supra note 16, at 64 . 
explains its vote in the General Assembly is a form of practice that can generate customary law. ${ }^{123}$ Then if emergent practice exists outside the resolution, the adoption of the resolution can serve as a collective expression of opinio juris that can crystallize the rule. In either case, "if governments choose to take their formal stance by means of a General Assembly resolution, there is no a priori reason why this should not count." ${ }^{124}$ Consistent with this, in the Nuclear Weapons Advisory Opinion, the ICJ noted "that General Assembly resolutions, even if they are not binding, may sometimes have normative value." 125

In deciding whether to treat a particular General Assembly resolution as evidence of an emergent rule of customary international law, the ICJ has stated that "it is necessary to look at its content and the conditions of its adoption." 126 In examining these factors, courts often consider the type of resolution to be significant. General Assembly resolutions fall within a spectrum, from mere "recommendations" (usually given little weight) to "Declarations" (used to impart increased solemnity) to "affirmations" (used to indicate codification or crystallization of law). ${ }^{127}$ Courts also consider the words used in the resolution; for example, language of firm obligation versus aspiration. ${ }^{128}$ In the same way that the amount of practice required to modify or overturn an existing rule will be greater than in cases where the matter has not previously been the subject of specific regulation in international law, General Assembly resolutions addressing "virgin territory" are better candidates for becoming law than those which counter existing rules. ${ }^{129}$

Another important consideration is the vote outcome. While resolutions passed unanimously or by sizable majorities could potentially have a law-generating affect, the existence of significant dissent, numerous abstentions, or even the objection of a handful of States that play an important part in the activities in question would prevent the crystallization

123. Id. at 41 .

124. Id. at 63 .

125. Nuclear Weapons Advisory Opinion, 1996 I.C.J. at 226.

126. Id. at 254-55.

127. General Introduction to the Standard-Setting Instruments of UNESCO, UNESCO, http://portal.unesco.org/en/ev.php-URL_ID=23772\&URL_DO=DO_TOPIC\&URL_SECTION=201.html (last visited May 11, 2014); see also Noelle Lenoir, Universal Declaration on the Human Genome and Human Rights: The First Legal and Ethical Framework at the Global Level, 30 COLUM. HUM. RTS. L. REV. 537, 551 (1999); Major Robert A. Ramey, Armed Conflict on the Final Frontier: The Law of War in Space, 48 A.F.L. REV. 1, 110 (2000).

128. Robert Rosenstock, The Declaration of Principles of International Law Concerning Friendly Relations: A Survey, 65 AM. J. INT'L. L. 713, 715-16 (1971).

129. INT'L LAW Ass'N, supra note 16, at 65 . 
from taking place. ${ }^{130}$ While one might be tempted to treat consensus resolutions (adopted without an actual vote) the same as those adopted unanimously, consensus resolutions may be discounted because countries often are pressured to remain silent (even if they have objections) so as not to break consensus. ${ }^{131}$ The ICJ has also indicated that if a State expressly mentions, while voting for a particular General Assembly Resolution, that it regards the text as being merely a political statement without legal content, then that resolution may not be invoked against it. ${ }^{132}$ For these reasons, fears that conferring upon General Assembly resolutions a role in the formation of customary law will transform the General Assembly into a world legislature and lead to tyranny of the majority are misplaced.

In the Nicaragua Case, the ICJ appears to have treated General Assembly Resolution 2625, the Declaration of Principles of International Law concerning Friendly Relations and Co-operation among States, as a resolution that generated customary international law. ${ }^{133}$ The Court stated that:

[T] understood as merely that of a 'reiteration or elucidation' of the treaty commitment undertaken in the Charter. On the contrary, it may be understood as an acceptance of the validity of the rule or set of rules declared by the resolutions by themselves. ${ }^{134}$

\section{The Sliding Scale Theory}

Washington and Lee Law Professor Frederic Kirgis suggests that there is a "sliding scale" relation between the amount of practice and opinio juris needed to produce a rule of customary international law. ${ }^{135}$ The greater the quantity of concordant practice, he argues, the less the need for evidence of opinio juiris. "At the other end of the scale, a clearly demonstrated opinio juris establishes a customary rule without much (or any) affirmative action showing that governments are consistently behaving in accordance with the

130. Nuclear Weapons Advisory Opinion, 1996 I.C.J. at 255.

131. Schwebel, supra note 116, at 302.

132. Nicaragua Case, 1986 I.C.J. at 106-07.

133. Id.

134. Id. at $99,7188$.

135. Frederic. L. Kirgis, Jr., Custom on a Sliding Scale, 81 AM. J. INT'L L. 146, 149 (1987). For other scholars that have endorsed Kirgis' sliding scale concept, see John Tasioulas, In Defense of Relative Normativity: Communitarian Values and the Nicaragua Case, 16 OXFORD J. OF LEGAL STUD. 85, 109 (1996); MENDELSON, supra note 27, at 386 
asserted rule."136 Professor Anthea Roberts criticizes Kirgis' concept because it tends to overemphasize one component at the expense of the other, potentially justifying instant customary law based solely on unanimously adopted General Assembly Resolutions. ${ }^{137}$

Taking an intermediate position, Professor Mendelson believes that Kirgis' sliding scale concept is particularly apt for areas not specifically regulated in international law. Citing the U.N. General Assembly resolutions on the rules governing exploration of outer space, Mendelson states that in such areas "the solemn enunciation of rules by which States as a whole intend to conduct themselves in the future should be binding."138 Echoing this view, referring to the legal status of General Assembly Resolution 95(I) endorsing the Nuremberg Principles, the Israeli Supreme Court stated in the 1962 Eichmann case that:

[I]f fifty-eight nations [i.e., all the members of the UN at the time] unanimously agree on a statement of existing law, it would seem that such a declaration would be all but conclusive evidence of such a rule, and agreement by a large majority would have great value in determining what is existing law. ${ }^{139}$

\section{THE GROTIAN MOMENT CONCEPT}

In domestic law, we know what stages legislation needs to go through and how many votes are needed at each stage for a bill to become a law. Likewise for international conventions, we know what formalities must be undertaken for a text to become a treaty and the number of ratifications required to bring it into force. In contrast, as discussed above, there exists no agreed upon formula for identifying with precision how many States are needed and how much time must transpire to generate a rule of customary international law. ${ }^{140}$

Professor Mendelson suggests that such a formula is unnecessary. Using the metaphor of building a house, he points out that it is often difficult or impossible to say exactly when construction has reached the point that we can conclude a house has been created. It is neither when the first foundation stone is laid nor when the last brush of paint has been

136. Kirgis, Jr., supra note 135 , at 149.

137. Roberts, supra note 48 , at 774 .

138. MENDELSON, supra note 27, at 386.

139. Attomey-General of Israel v. Eichmann, 36 I.L.R. 277, ๆ 11 (May 29, 1962).

140. D'AMATO, supra note 45 , at 58 (noting that there is no consensus as to how much time a practice must be maintained to evidence the existence of a custom); Tunkin, supra note 2 , at 420 (arguing that the element of time is not dispositive as to whether a customary rule exists). 
applied, but somewhere between the two. "Do we have to wait for the roof to go on, for the windows to be put in, or for all of the utilities to be installed? So it is with customary law." ${ }^{141}$ Rarely does a decision maker need to know the exact moment that a practice has crystallized into a binding rule, or as Mendelson puts it "precisely when the fruit became ripe." Instead, he concludes, "we are more interested in knowing, when we bite it, if it is now ripe or still too hard or sour."142

Mendelson's metaphor is apt, for example, in examining when the continental shelf concept became customary international law. President Truman proclaimed the continental shelf concept in 1945; the 1958 Geneva Convention on the Continental Shelf recognized this entitlement on the part of coastal States, and in 1969 the ICJ acknowledged that the principle was part of customary international law in North Sea Continental Shelf. ${ }^{143}$ Somewhere during those twenty-four years between 1945 and 1969, the coastal States' rights over the continental shelf had crystallized into customary international law, but it would be difficult to pinpoint the exact moment that occurred.

But sometimes courts need to determine more definitively when an emerging norm has ripened into binding customary international law. The Cambodia Tribunal's determination of whether Joint Criminal Enterprise Liability existed as a principle of customary international law in 1975 is illustrative.

\section{A. Nuremberg as Grotian Moment}

During a sabbatical in the fall of 2008, I had the unique experience of serving as Special Assistant to the International Prosecutor of the Extraordinary Chambers in the Courts of Cambodia, the tribunal created by the U.N. and government of Cambodia to prosecute the former leaders of the Khmer Rouge for the atrocities committed during their reign of terror 1975 to $1979 .{ }^{144}$ While in Phnom Penh, my most important assignment was

141. MENDELSON, supra note 27, at 175.

142. Id. at 176.

143. North Sea Continental Shelf, 1969 I.C.J. at 3; White House News Release, President Truman's Proclamations on U.S. Policy Concerning Natural Resources of Sea Bed and Fisheries on High Seas (Sept. 28, 1945), available at http://www.ibiblio.org/pha/policy/post-war/1945-09-28a.html (last visited May 12, 2014).

144. For background on the creation of the ECCC, see generally Michael P. Scharf, Tainted Provenance: When, If Ever, Should Torture Evidence be Admissible?, 65 WASH. \& LEE L. REV. 129 (2008). 
to draft the Prosecutor's brief ${ }^{45}$ in reply to the Defense Motion to Exclude Joint Criminal Enterprise (JCE) liability as a mode of liability from the trial of the five surviving leaders of the Khmer Rouge. ${ }^{146}$

JCE is a form of liability somewhat similar to the Anglo-American "felony murder rule,", and the "Pinkerton rule,", in which a person who willingly participates in a criminal enterprise can be held criminally responsible for the reasonably foreseeable acts of other members of the criminal enterprise even if those acts were not part of the plan. Although few countries around the world apply principles of co-perpetration similar to the felony murder rule or Pinkerton rule, since the decision of the Appeals Chamber of the International Criminal Tribunal for the Former Yugoslavia in the 1998 Tadic case, ${ }^{149}$ it has been accepted that JCE is a mode of liability applicable to international criminal trials. Dozens of cases before the Yugoslavia Tribunal, the International Criminal Tribunal for Rwanda, the Special Court for Sierra Leone, the Special Panels for the Trial of Serious Crimes in East Timor, and the Special Tribunal for Lebanon have recognized and applied JCE liability during the last ten years.

These modern precedents, however, were not directly relevant to the Cambodia Tribunal because the crimes under its jurisdiction had occurred some twenty years earlier. Under the international law principle of nulem crimin sine lege (the equivalent to the U.S. Constitution's ex post facto law prohibition), the Cambodia Tribunal could only apply the substantive law and associated modes of liability that existed as part of customary international law in 1975. Therefore, the question at the heart of the brief

145. Co-Prosecutors' Supplementary Observations on Joint Criminal Enterprise, Case of Ieng Sary, No. 002/19-09-2007-ECCC/OCIJ, 31 December 2009. A year later, the Co-Investigating Judges ruled in favor of the Prosecution that the ECCC could employ JCE liability for the international crimes within its jurisdiction. See Order on the Application at the ECCC of the Form of Liability Known as Joint Criminal Enterprise, Case No. 002/19-09-2007-ECCC-OCIJ, 8 December 2009.

146. Pursuant to the Co-Investigating Judges' Order of 16 September 2008, the Co-Prosecutors filed the brief to detail why the extended form of JCE liability, "JCE III," is applicable before the ECCC. The Defense Motion argued in part that JCE III as applied by the Tadic decision of the International Criminal Tribunal for the former Yugoslavia (ICTY) Appeals Chamber is a judicial construct that does not exist in customary international law or, alternatively, did not exist in 1975-79. Case of Ieng Sary, leng Sary's Motion against the Application at the ECCC of the Form of Responsibility Known as Joint Criminal Enterprise, Case No. 002/19-09-2007-ECCC/OCIJ, 28 July, 2008, ERN 00208225-00208240, D97.

147. For background about, and cases applying, see generally David Crump \& Susan Waite Crump, In Defense of the Felony Murder Doctrine, 8 HARV. J.L. \& PUB. POL'Y 359 (1985).

148. For background about, and cases applying the Pinkerton Rule, see generally Matthew A. Pauley, The Pinkerton Doctrine and Murder, 4 PIERCE L. REV. 1 (2005).

149. Prosecutor v. Tadic, Case No. IT-94-1-I, Judgment, (Int'l Crim. Trib. for the Former Yugoslavia July 15, 1999). 
that I drafted was whether the Nuremberg Tribunal precedent and the U.N.'s adoption of the "Nuremberg Principles" were sufficient to establish JCE liability as part of customary international law following World War II.

The attorneys for the Khmer Rouge Defendants argued that Nuremberg and its progeny provided too scant a sampling to constitute the widespread state practice and opinio juris required to establish JCE as a customary norm as of $1975 .{ }^{150}$ In response, the Prosecution brief I drafted maintained that Nuremberg constituted "a Grotian Moment"-an instance in which there is such a fundamental change to the international system that a new principle of customary international law can arise with exceptional velocity. This was the first time in history that the term was used in a proceeding before an international court. Despite the dearth of State practice, the Cambodia Tribunal ultimately found JCE applicable to its trials based on the Nuremberg precedent and U.N. General Assembly endorsement of the Nuremberg Principles. ${ }^{151}$

While the Nuremberg trials were not without criticism, there can be no question that Nuremberg represented a paradigm-shifting development in international law. The ILC has recognized that the Nuremberg Charter and Judgment gave birth to the entire international paradigm of individual criminal responsibility. Prior to Nuremberg, the only subjects of international law were States, and what a State did to its own citizens within its own borders was its own business. Nuremberg fundamentally altered that conception. "International law now protects individual citizens against abuses of power by their governments [and] imposes individual liability on government officials who commit grave war crimes, genocide, and crimes against humanity." 152 The ILC has described the principle of individual responsibility and punishment for crimes under international law recognized at Nuremberg as the "cornerstone of international criminal law" and the "enduring legacy of the Charter and Judgment of the Nuremberg Tribunal." 153

150. For the definition of "customary international law," see North Sea Continental Shelf, 1969 I.C.J. ๆ 77.

151. In Case 002, the ECCC Pre-Trial Chamber later confirmed that JCE I and JCE II reflected customary international law as of 1976, but questioned whether JCE III was actually applied at Nuremberg, and therefore was not applicable to the ECCC trial. Decision on the Appeals Against the Co-Investigative Judges' Order on Joint Criminal Enterprise (JCE), leng et al. (002/10-09-2007ECCC/TC), Trial Chamber, 17 June, 2011.

152. Slaughter \& Burke-White, supra note 9, at 13.

153. See Rep. of the Int'l Law Comm'n on the Work of its Forty-Eighth Session, 51st Sess., May 6-July 26, 1996, U.N. Doc. A/51/10; GAOR, 51st Sess., Supp. No. 10 (1996), available at http://legal.un.org/ilc/documentation/english/A_51_10.pdf (last visited Feb. 22, 2014). 
Importantly, on December 11,1946, in one of the first actions of the newly formed U.N., the General Assembly unanimously affirmed the principles from the Nuremberg Charter and judgments in Resolution 95(I). ${ }^{154}$ This General Assembly Resolution had all the attributes of a resolution entitled to great weight as a declaration of customary international law: It was labeled an "affirmation" of legal principles; it dealt with inherently legal questions; it was passed by a unanimous vote; and none of the members expressed the position that it was merely a political statement. ${ }^{155}$

Despite the fact that Nuremberg and its Control Council Law \#10 progeny consisted of only a dozen separate cases tried by a handful of courts over a period of just three years, the ICJ, ${ }^{156}$ the International Criminal Tribunal for the Former Yugoslavia, ${ }^{157}$ the European Court of

154. Affirmation of the Principles of International Law Recognized by the Charter of the Nürnberg Tribunal, G.A. Res. 95(I), U.N. GAOR, 1st Sess., U.N. Doc A/236, pt. 2, at 1144, (Dec. 11, 1946), available at http:/www.un.org/en/ga/search/view_doc.asp?symbol=A/RES/95(I)\&Lang= E\&Area=RESOLUTION (last visited Feb. 22, 2014). The Resolution states in whole:

The General Assembly,

Recognizes the obligation laid upon it by Article 13, paragraph 1, sub-paragraph a, of the Charter, to initiate studies and make recommendations for the purpose of encouraging the progressive development of international law and its codification;

Takes note of the Agreement for the establishment of an International Military Tribunal for the prosecution and punishment of the major war criminals of the European Axis signed in London on 8 August 1945, and of the Charter annexed thereto, and of the fact that similar principles have been adopted in the Charter of the International Military Tribunal for the trial of the major war criminals in the Far East, proclaimed at Tokyo on 19 January 1946;

Therefore,

Affirms the principles of international law recognized by the Charter of the Nuremberg Tribunal and the judgment of the Tribunal;

Directs the Committee on the codification of international law established by the resolution of the General Assembly of 11 December 1946, to treat as a matter of primary importance plans for the formulation, in the context of a general codification of offenses against the peace and security of mankind, or of an International Criminal Code, of the principles recognized in the Charter of the Nürnberg Tribunal and in the judgment of the Tribunal. $I d$.

155. See supra notes $126-132$ and accompanying text.

156. Legal Consequences of the Construction of a Wall in Occupied Palestinian Territory, Advisory Opinion, 2004 I.C.J. 136, 172 (July 9).

157. Prosecutor v. Tadic, Case No. IT-94-1-I, Opinion and Judgment, Trial Chamber, I 623 (Int'l Crim. Trib. for the Former Yugoslavia May 7, 1997); Prosecutor v. Tadic, Case No. IT-94-1-I, Decision on the Defence Motion for Interlocutory Appeal on Jurisdiction, $\mathbb{1} 141$ (Int'l Crim. Trib. for the Former Yugoslavia Oct. 2, 1995). 
Human Rights, ${ }^{158}$ and several domestic courts ${ }^{159}$ have cited the General Assembly Resolution affirming the principles of the Nuremberg Charter and judgments as an authoritative declaration of customary international law.

Nuremberg, then, constitutes a prototypical Grotian Moment. The Tribunal's formation was in response to the most heinous atrocity in the history of humankind-the extermination of six million Jews and several million other "undesirables" by the Nazi regime. From a conventional view of customary international law formation, the amount of State practice was quite limited, consisting only of the negotiation of the Nuremberg Charter by four States, its accession by nineteen others, the judgment of the Tribunal, and a General Assembly Resolution endorsing (though not enumerating) its principles. Moreover, the time period from the end of the war to the General Assembly endorsement of the Nuremberg Principles was a mere year, a drop in the bucket compared to the amount of time it ordinarily takes to crystallize customary international law. Yet, despite the limited state practice and minimal time, the ICJ, European Court of Human Rights, and four international criminal tribunals have confirmed that the Nuremberg Charter and Judgment immediately ripened into customary international law.

The Grotian Moment concept rationalizes this outcome. Nuremberg reflected a novel solution to unprecedented atrocity in the context of history's most devastating war. Beyond the Nuremberg trial, there was a great need for universal implementation of the Nuremberg Principles. Yet, on the eve of the Cold War, it was clear that a widely ratified multilateral convention would not be a practicable near term solution. In fact, it would take half a century before the international community was able to conclude

158. The European Court of Human Rights recognized the "universal validity" of the Nuremberg principles in Kolk and Kislyiy v. Estonia, which stated:

Although the Nuremberg Tribunal was established for trying the major war criminals of the European Axis countries for the offences they had committed before or during the Second World War, the Court notes that the universal validity of the principles concerning crimes against humanity was subsequently confirmed by, inter alia, resolution 95 of the United Nations General Assembly (11 December 1946) and later by the International Law Commission.

See Kolk and Kislyiy v. Estonia, App. No. 23052/04, 24018/04, Decision on Admissibility, Eur. Ct. H.R. (Jan. 17, 2006).

159. The General Assembly resolution affirming the Nuremberg Principles has been cited as evidence of customary international law in cases in Canada, Bosnia, France, and Israel. See R. v. Finta, [1994], 1 S.C.C. 701 (Can.); Prosecutor v. Ivica Vrdoljak, Court of Bosnia and Herzegovina, 10 July 2008; see generally Leila Sadat Wexler, The Interpretation of the Nuremberg Principles by the French Court of Cassation: From Touvier to Barbie and Back Again, 32 COLUM. J. TRANSNAT'L L. 289 (1994) (summarizing the Touvier and Barbie cases in French courts). 
a widely ratified treaty transforming the Nuremberg model into a permanent international criminal court. It is this context of fundamental change and great need for a timely response that explains how Nuremberg could so quickly and universally be accepted as customary international law.

\section{B. Other Examples of Grotian Moments Since World War II}

As the Max Planck Encyclopedia of Public International Law has observed, "recent developments show that customary rules may come into existence rapidly."

This can be due to the urgency of coping with new developments of technology, such as, for instance, drilling technology as regards the rules on the continental shelf, or space technology as regards the rule on the freedom of extra-atmospheric space. Or it may be due to the urgency of coping with widespread sentiments of moral outrage regarding crimes committed in conflicts such as those in Rwanda and Yugoslavia that brought about the rapid formation of a set of customary rules concerning crimes committed in internal conflicts. ${ }^{161}$

Consistent with this observation, Chapter Five of my book, Customary International Law in Times of Fundamental Change: Recognizing Grotian Moments, recounts the history of President Truman's 1945 Proclamation that the resources on the continental shelf off the coast of the United States belonged to the United States. This represented a major departure from the existing customary international law of the sea. The Proclamation was driven by technological developments enabling exploitation of offshore oil and gas supplies and the intense post-war demand for such resources for a rebuilding world. Though the United States recognized that it was acting as a custom pioneer, it was careful to couch its justification in legal terms that would render the action easier to accept and replicate by other States. Despite the far-reaching change it represented, the Truman Proclamation was met with no protest; rather, within five years, half of the world's coastal States had made similar claims to the resources of their continental shelves, leading commentators to declare that the continental shelf concept had become virtually instant customary international law. By 1969, the ICJ had confirmed that the Truman Declaration quickly generated customary international law binding on States that had not ratified the 1958 Law of the Sea Convention.

160. Treves, supra note 22, ๆ 24; accord INT'L LAW ASs'N, supra note 16, at 20.

161. Id. 
Chapter Six of my book examines the customary international law that rapidly emerged from the great leaps in rocket technology in the 1960s, led by the Soviet Union and the United States, inaugurating the era of space flight. Rather than treat outer space like the high seas, the international community embraced a unique set of rules to govern this new area as codified in the General Assembly Declaration on Outer Space, which was unanimously approved in 1963 . Though the amount of State practice was limited to a few dozen space flights launched by two States and the lack of protest by the States over which these rockets passed, States and scholars have concluded that the 1963 Declaration represented an authoritative statement of customary international law that rapidly formed in response to new technologies requiring a new international law paradigm.

Chapter Seven analyzes the customary international law that rapidly emerged from the Yugoslavia Tribunal in the 1990s. The establishment of the Yugoslavia Tribunal was made possible because of a unique constellation of events at the end of the Cold War, which included the break-up of the Soviet Union, Russia's assumption of the Soviet seat in the Security Council, and the return of genocide to Europe for the first time since Nazi Germany. In its inaugural case, the Appeals Chamber of the Yugoslavia Tribunal rendered a revolutionary decision that for the first time held that individuals could be held criminally liable for violations of Common Article 3 and Additional Protocol II of the Geneva Conventions for war crimes committed in internal conflict. This decision closed a gaping gap in the coverage of international humanitarian law and was soon thereafter affirmed by the Rwanda Tribunal and Special Court for Sierra Leone. It was codified in the 1998 Statute of the International Criminal Court, which has been ratified by 122 States.

These case studies suggest that the Grotian Moment concept has several practical applications. It can explain the rapid formation of customary rules in times of rapid flux, thereby imbuing those rules with greater repute. It can counsel governments when to seek the path of a U.N. General Assembly resolution as a means of facilitating the formation of customary international law, and how to craft such a resolution to ensure that it is viewed as a capstone in the formation of such customary rules. It can in apt circumstances strengthen the case for litigants arguing the existence of a new customary international rule. It can also furnish international courts the confidence to recognize new rules of customary international law in appropriate cases despite a relative paucity and short duration of State practice.

At the same time, one must approach the Grotian Moment concept with caution. As one author warns, "[i]t is always easy, at times of great 
international turmoil, to spot a turning point that is not there." ${ }^{162}$ Thus, it is with the case studies examined in Chapters Eight and Nine of my book, which also manifested many of the attributes of a Grotian Moment, but in each careful examination revealed that an essential ingredient was lacking to bring the crystallization of customary international law to realization.

As Chapter Eight of my book details, in contrast to earlier cases of unilateral humanitarian intervention, which had been met with widespread condemnation, the North Atlantic Treaty Organization (NATO) airstrikes against Serbia to protect Kosovar Albanians from ethnic cleansing in 1999 engendered widespread support by the international community. In its formulation of the Responsibility to Protect Doctrine two years later, the Report of the International Commission on Intervention and State Sovereignty (ICISS) provided a novel legal veneer for unilateral humanitarian intervention that seemed poised to quickly develop into customary international law. But the principal States behind the NATO intervention retreated from the position that their acts were a lawful exercise of unilateral humanitarian intervention, emphasizing instead the exceptional nature of the military operation. These statements effectively slowed momentum for the ripening of a new rule of customary international law. Then, while the U.N. was considering steps to endorse the ICISS Report and Responsibility to Protect Doctrine, the United States launched a controversial invasion of Iraq in 2003, citing humanitarian concerns as one of the justifications for its action. Rather than endorsing unilateral humanitarian intervention, the U.N. General Assembly and Security Council ended up with a formulation that instead reaffirmed the importance of Security Council authorization before States or Regional Organizations can take such action. While the Responsibility to Protect concept has influenced the international debate related to responding to various crisis, it did not end up representing a fundamental change in the law of intervention.

Chapter Nine of my book examines the response to the terrorist attacks of September 11, 2001. Prior to the September 11th attacks, international law required attribution to the territorial State before a victim State could launch an extraterritorial attack in self-defense against non-state actors present there. That requirement appeared to be fundamentally altered when the international community widely approved the United States military action against al-Qaeda in Afghanistan as lawful force in self-defense. AlQaeda was widely viewed as representing a new kind of threat, in which a non-state actor possessed many of the attributes of a State-independent

162. Ibrahim J. Gassama, International Law at a Grotian Moment: The Invasion of Iraq in Context, 18 EMORY INT'L L. REV. 1, 30 (2004). 
wealth, willing forces with global reach, sophisticated training and organization using newly developed communications technology, and potential access to weapons of mass destruction. Moreover, the tactics of al-Qaeda were to attack without warning, target civilians indiscriminately, and employ suicide missions on a regular basis. In response, the so-called Bush Doctrine was devised to permit States to target key al-Qaeda figures and destroy al-Qaeda bases in weak or failed States that had proven unwilling or unable to prevent al-Qaeda from operating in their territory. But lacking nuance, the broadly articulated Bush Doctrine provoked pushback from the ICJ, which, in the 2004 Wall and 2005 Congo cases, reaffirmed that State attribution remained a perquisite for using force in self-defense. In light of the widespread criticism of these holdings, including from some of the ICJ's most respected members, this judicial action is unlikely to be the final word, but in the short-term they have weakened the capacity for the law of $9 / 11$ to blossom into a Grotian Moment.

Taken together, the six case studies examined in Customary International Law in Times of Fundamental Change: Recognizing Grotian Moments provide several valuable insights about the nature and function of the Grotian Moment concept. In all six case studies, the (potential) Grotian Moment began with a custom pioneer-a state willing to initiate a new practice contrary to existing customary international law in order to create a new rule of customary international law. However, none of these pioneers took the position that they were breaking new ground. Rather, they followed an approach that can be likened to putting new wine in old bottles, characterizing their innovations as consistent with existing law, though in fact they were fermenting a new vintage.

Moreover, the case studies indicate that in addition to responding to technological, economic, or societal change, Grotian Moments are in part made possible by geopolitical realignment, often following war. Thus, the affirmation of the Nuremberg Principles and the development of the continental shelf concept followed in the immediate aftermath of the conclusion of World War II. Similarly, the establishment of the Yugoslavia Tribunal and issuance of the Tadic decision on the application of war crimes to internal armed conflicts occurred during a unique period following the end of the Cold War and collapse of the Soviet Union. The international community's response to the attacks of $9 / 11$ appeared to represent a geopolitical realignment in the common cause against terrorism, but subsequent actions by the United States, such as the mistreatment of terrorist detainees at Guantanamo Bay and CIA Black sites, fractured the growing consensus about when, where, and how to employ force against non-state actors. 
Further, in the cases of Nuremberg, the continental shelf, and space law, the Grotian Moments led to rapid formation of fundamental principles of customary international law though definitional ambiguities (e.g., with respect to the precise meaning of aggression, continental shelf, and outer space) continued to be worked out and evolve in subsequent years. This indicates that the rapidly formed customary international law resulting from a Grotian Moment does not have to be fully fleshed out or rigidly fashioned in order to represent a radical change in the law.

Significantly, several of the case studies attest to the important role that General Assembly resolutions can play as an essential ingredient in bringing a Grotian Moment to fruition. The 1946 Declaration affirming the Nuremberg Principles and the 1963 Declaration on Outer Space are examples of General Assembly resolutions that had a significant impact on the formation and codification of customary international law. The form, content, and context of these resolutions enhanced their role as midwife to the birth of customary rules despite the limited State practice on which the resolutions were based. Conversely, the case study of the 1999 NATO intervention demonstrated how General Assembly and Security Council resolutions could derail a potential Grotian Moment from reaching its destination.

Similarly, the case studies of space law and the Tadic decision also demonstrated how negotiation of a multilateral treaty could culminate a Grotian Moment. The 1969 Space Treaty rechristened the rules of customary international law that were codified in the 1963 General Assembly Declaration. The negotiation of the 1998 Rome Statute of the International Criminal Court confirmed the customary international law status of the application of war crimes to international armed conflict that was articulated just three years earlier by the Yugoslavia Tribunal. Because they represented customary rules, the provisions of these treaties on space law and war crimes liability were deemed applicable to non-parties and parties alike.

Likewise, in some of the case studies, the decisions of international tribunals supplied the authoritative gloss that completed the Grotian Moment by confirming the existence of the new rule of customary law. North Sea Continental Shelf, for example, confirmed the customary law status of the Truman Proclamation. In contrast, the Wall and Congo set back the crystallization of the law of self-defense against terrorist groups whose conduct is not attributable to the State that harbors them. Thus, like General Assembly resolutions, international court decisions take on a heightened significance in the process of norm creation during a potential Grotian Moment. 
The case studies also provide support for Professor Bederman's supposition that previously unregulated realms are fertile territory for accelerated formation of customary international law. ${ }^{163}$ Bederman's thesis helps explain the rapid crystallization of space law, the Nuremberg Principles, the continental shelf, and the application of war crimes to internal armed conflict. It also helps explain why the International Court has been reluctant to depart from the attribution requirement articulated in its 1986 Nicaragua precedent in the context of post $9 / 11$ use of force in selfdefense against non-state actors in Third States.

The final two case studies examined in Chapters Eight and Nine of my book indicate how a quickly ripening norm can be set back by State practice or articulations that constitute a perceived abuse of the norm. Thus, the United States' invasion of Iraq in 2003 and the Russian invasion of Georgia in 2008 renewed concerns that a doctrine permitting unilateral humanitarian intervention would be easily subject to abuse, thereby derailing the momentum that had been gaining behind the responsibility to protect concept as legal justification for humanitarian action outside the U.N. framework. Similarly, perceptions that the Bush Doctrine was overbroad and easily subject to abuse slowed momentum for a change in the law of self-defense against non-state actors.

Finally, while some scholars have characterized one or more of these cases as "virtual instant custom," the Grotian Moment concept is to be distinguished from the controversial notion of instant custom. Grotian Moments represent instances of rapid, as opposed to instantaneous, formation of customary international law. In addition to General Assembly resolutions and international court decisions, Grotian Moments require some underpinning of State practice, whereas advocates of the concept of instant custom argue that customary law can form in the absence of State practice. The necessary State practice during a Grotian Moment can precede the General Assembly resolution consistent with Professor McDougal's "claim and response" approach, ${ }^{164}$ or it can follow the resolution as envisioned in Professor D'Amato's "articulation and act" approach, ${ }^{165}$ but in none of the case studies did the States' vote on the resolutions themselves provide the only foundation of State practice.

163. Bederman, supra note 14 , at 38 .

164. See generally Myres S. McDougal \& Norbert A. Schlei, The Hydrogen Bomb Tests in Perspective: Lawful Measures for Security, 64 YALE L.J. 648 (1955).

165. D'AMATO, supra note 45 , at 88. 


\section{CONCLUSION}

Despite the distinction between so-called "instant custom" and the phenomenon of Grotian Moments, some States and commentators may not welcome the articulation of a concept that rationalizes rapid formation of customary international law. For some, international law is best created exclusively through treaties, as to which States can opt out by non-action, simply by declining to ratify the instrument. So long as customary norms take many decades to ripen into law, customary international law does not seem threatening. But it is another matter if customary law can form within just a few years and is deemed binding on States that have not affirmatively manifested their persistent objection. In such cases, they may fear a concept of law formation that appears more revolutionary than evolutionary.

At the same time, the case studies of Grotian Moments demonstrate international recognition that customary international law must have the capacity in unique circumstances to respond to rapidly evolving developments by producing rules in a timely and adequate manner. They also demonstrate that not every momentous technological, geo-political, or societal change results in accelerated formation of customary international law-like for recrystallized gem stones, true Grotian Moments are both precious and relatively rare. So, where will we see the next bona fide Grotian Moment? I have my eye on the emerging customary international law related to the disappearance of island states due to rising sea levels caused by global warming. ${ }^{166}$

166. In August 2012, the International Law Association established a committee to "study the possible impacts of sea-level rise and the implications under international law of the partial and complete inundation of state territory, or depopulation thereof, in particular of small island and lowlying states;" and to "develop proposals for the progressive development of international law in relation to the possible loss of all or of parts of state territory and maritime zones due to sea-level rise, including the impacts on statehood, nationality, and human rights." International Law and Sea Level Rise, INT'L LAW Ass'N, http://www.ila-hq.org/en/committees/index.cfm/cid/1043 (last visited Feb. 22, 2014). 